\title{
ORAL VERSUS TOPICAL PROPRANOLOL IN MANAGEMENT OF INFANTILE HEMANGIOMA
}

By

\author{
Ahmed A. Khattab, Samir H. Gouda and Abd El-Wahab Y. El-Okby \\ Pediatric Surgery Department, Faculty of Medecine, AlAzhar University \\ E-mail: ahmedabdalla18@yahoo.com
}

\begin{abstract}
Background: Infantile hemangiomas (IHs) are the most common soft tissue tumors of infancy, which occur in $4 \%$ to $10 \%$ of children under 1 year of age. Female infants are three to four times more likely suffering from IH as male infants. Hemangioma may require no treatment except if any complications occur.
\end{abstract}

Objective: To compare the efficacy of orally administered propranolol versus topical propranolol in the management of infantile hemangiomas in infants and children below 7 years of age.

Patients and Methods: These studies were conducted on 40 patients attending to Egyptian Military Hospitals with Infantile hemangioma, and were divided into two groups: Group A received oral propranolol and Group B received topical propranolol for 6 months in both groups, this was from February 2019 to November 2019.

Results: Oral and topical propranolol achieved a satisfactory results with no significant difference in both groups, with mean reduction in size of $36.55 \%$ and $34.54 \%$ respectively according to U/S. No significant difference in visual analogue scale (VAS). Complications rate among the two groups were $25 \%$ and $10 \%$ respectively in the form of relapse, hypoglycemia and broncho spasm in oral group, while relapse was with topical group.

Conclusion: Oral and topical propranolol have a good effect in management of IH, with no significant difference of both. We recommend usage of topical propranolol as first option especially in superfacial type.

Keywords: Infantile hemangioma; topical propranolol; systemic propranolol; soft tissue tumors.

\section{INTRODUCTION}

Infantile hemangiomas (IHs) are noncancerous growth of blood vessels, occurring in $4 \%$ to $10 \%$ of children under 1 year of age, they can occur anywhere on the body but most commonly appear on face, scalp, chest and back. They enter a phase of rapid growth within the first weeks of life, lasting for 3 to 6 months which may go on for 24 months, then a period of stabilization followed by spontaneous involution usually occurring in several years. According to the depth of tissue involvement, IH could be divided into three main types; superficial, deep and mixed hemangiomas. Although most IHs does not require urgent treatment, a minority may develop functionthreatening or life threatening complications, necessitating therapeutic intervention. Site of the $\mathrm{IH}$ has a great bearing on symptoms and prognosis. An orbital apical lesion tends to cause visual defects by compressing the optic nerve. Lesions in the external auditory canal can lead to conductive deafness. So, site of IH may indicate the need for further investigations. Consequently, the decision 
if to start treating $\mathrm{IHs}$ or not has been controversial over the last decades owing to the unique pattern of growth, yet, studies showed that most untreated lesions did not improve after 3-5 years of age, and more than $50 \%$ of untreated cases showed significant residuum. Therefore, many clinicians recommend early active intervention rather than "wait and see" strategy (Baselga et al., 2016). In 2008, Léauté-Labrèze reported that oral propranolol, a non-selective Betaadrenergic blocker used for decades for treating cardiac disorders in children, is effective and well tolerated in the management of IH. For most clinicians treating complicated IHs, propranolol has become the $1^{\text {st }}$ line medical therapy; however, optimal dosing, treatment duration, timing, and risk of complications have not yet been established in randomized trials, and recommendations for monitoring are still evolving (Drolet et al., 2013). For discontinuation of treatment, gradual tapering of the dose over 1 - 3 weeks basically to avoid rebound sinus tachycardia. Timolol maleate is non-selective beta blockers, available in topical forms. Many studies show responses best in patients who had superficial IHs, applying $t \quad 0.5 \%$ gelforming solution, and used it twice daily for more than 3 months (Semkova et al., 2013).

The present work aimed to compare the efficacy of orally administered propranolol versus topical propranolol in the mangement of infantile hemangiomas in infants and children below 7 years of age.

\section{PATIENTS AND METHODS}

A prospective, randomized controlled clinical trial for forty patients with infantile hemangiomas in different parts of the body with different types. Patients were subdivided into two equal groups: Group A received oral propranolol and Group B received topical propranolol during the period from February 2019 to November 2019. The protocol was approved by the Research Ethical Committee, Faculty of Medicine, Al Azhar University. The authors obtained informed consents from the parents of all patients prior to the procedures. Group A was given propranolol at a starting dose of $2 \mathrm{mg} / \mathrm{kg}$ per day orally in three divided doses. In case of adequate response with only minor side effects, the drug was continued at $2 \mathrm{mg} / \mathrm{kg} / \mathrm{day}$ for 6 months. Blood pressure, heart rate and blood glucose level were monitored. Group B: Topical propranolol was given in the form of propranolol- hydrochloride at $1 \%$ concentration in hydrophobic ointment form. The amount of ointment applied was based on the surface area of the lesion and the ointment was rubbed three times daily for 6 months onto the clean dry IH area.

\section{Statistical analysis:}

We analyzed the data using Statistical Package for Social Science (SPSS) v 22.0 for windows. A paired-samples $t$ - tests was used to determine the statistically results. Data was expressed as mean \pm SD. Significance were considered when $\mathrm{P}$ $\leq 0.05$. 


\section{RESULTS}

Both oral and topical propranolol achieved a satisfactory outcome. Age of patients in group A ranged from 1 month to 4.5 years with the mean age was 13.5 months at time of starting the treatment (range 1 month-4.5 years) and was 19.4 months (range 7 months-5.1 years) at time of stopping the treatment. In Group B, the age of patients ranged from 1 month to 4 years with the mean age at starting the treatment was 12 months (range 1month4years). At time of termination the mean age was 18.2 months (range 7 months-4.5 years) (Table 1). Hemangioma in head \& neck was $75 \%$, in trunk was $15 \%$, in limbs was $7.5 \%$ and in genitalia was $2.5 \%$ (Chart 1) Regarding the type of IHs, it was superficial in $75 \%$, deep in $5 \%$, and Mixed in 20\% (Chart 2).

\section{Table (1): Age of Patients in (months)}

\begin{tabular}{|c|c|c|c|c|c|c|c|c|c|}
\hline \multirow{2}{*}{ Age } & \multicolumn{3}{|c|}{ Age at Start } & \multicolumn{3}{c|}{ Age at Termination } & \multicolumn{3}{c|}{ Follow up } \\
\cline { 2 - 10 } & Mean & SD & Mode & Mean & SD & Mode & Mean & SD & Mode \\
\hline Group A & 13.5 & 3.3 & 2 & 19.4 & 3.2 & 8 & 2.5 & 0.97 & 3 \\
\hline Group B & 12 & 3.1 & 1 & 18.2 & 3.1 & 7 & 3 & 1 & 3 \\
\hline
\end{tabular}

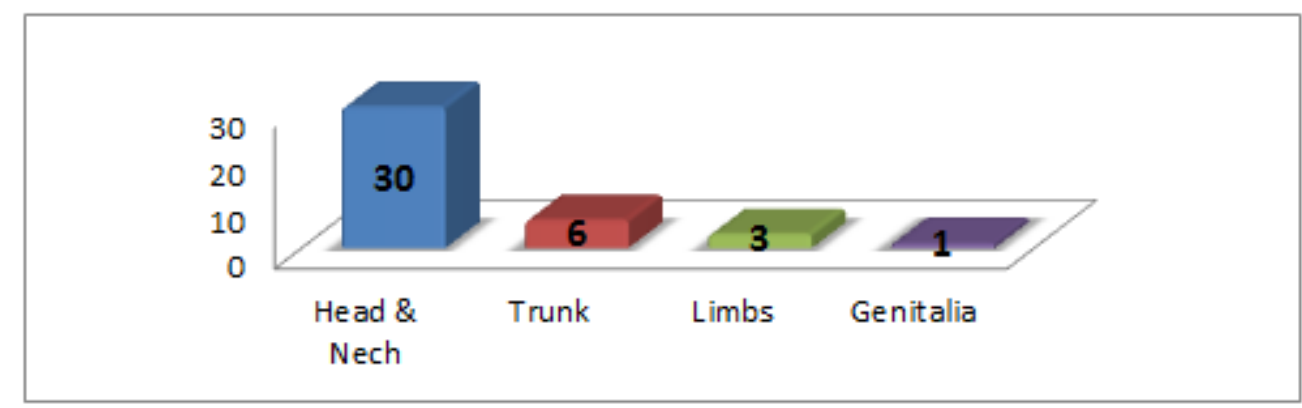

Chart (1): Sites of hemangiomas

\section{Type of hemangioma}
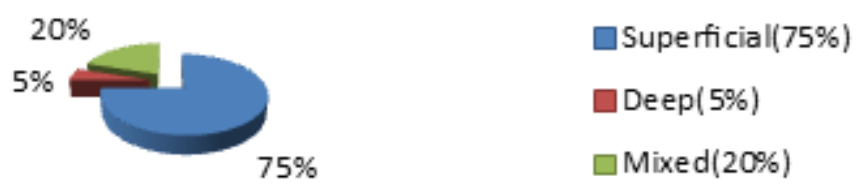

Chart (2): Types of Hemangiomas

The authors accounted on the ultrasonography to measure the overall reduction of size in the lesions after completion of the treatment. The authors measured the maximum diameter in two axes perpendicular to each other, at two points with starting the treatment and at time of termination. In Group A the mean reduction was $36.55 \%$ while in Group B was $34.54 \%$. Statistically there was no significant difference between the two groups (Table 2). As regarding colour fading; the authors calculated the results after 1 month, 3 months, 6 months based on Visual Analogue Scale (VAS). Although the degree of colour fading by the end of the treatment course was higher in Group A by recording $-7( \pm 1.5)$ when 
compared to Group B $-6( \pm 2.5)$, yet there was no significant statistical difference between the two groups (Table 3). The authors measured the degree of flattening of the lesions by using VAS also in the same time intervals, which showed, In Group A there was improvement especially in the first 3 months of therapy, and at 6 months the two groups achieved closely the same results, however this was not statistically significant with P- value 0.085 (Chart 4). Within the first 3 to 4 months of using systemic propranolol the major response on IH occurs. ECG is often ordered as well, particularly in younger infants, and those with an examination or family history consistent with congenital heart disease.

Table (2): Reduction in size

\begin{tabular}{|c|c|c|c|}
\hline Groups & Mean & SD $( \pm)$ & \multirow{2}{*}{ P-Value } \\
\hline Group A & $36.85 \%$ & 11.9 & \multirow{2}{*}{0.18} \\
\hline Group B & $34.74 \%$ & 9.2 & \\
\hline
\end{tabular}

Table (3): Mean change in the degree of fading based on VAS, and the SD

\begin{tabular}{|c|c|c|c|c|}
\hline Groups & 1 month & 3 months & 6 months & P-value \\
\hline Group A & $-2( \pm 0.9)$ & $-3.5( \pm 1.1)$ & $-5( \pm 1.1)$ & \multirow{2}{*}{0.34} \\
\hline Group B & $-1.5( \pm 0.64)$ & $-3( \pm 2.1)$ & $-4( \pm 2)$ & \\
\hline
\end{tabular}

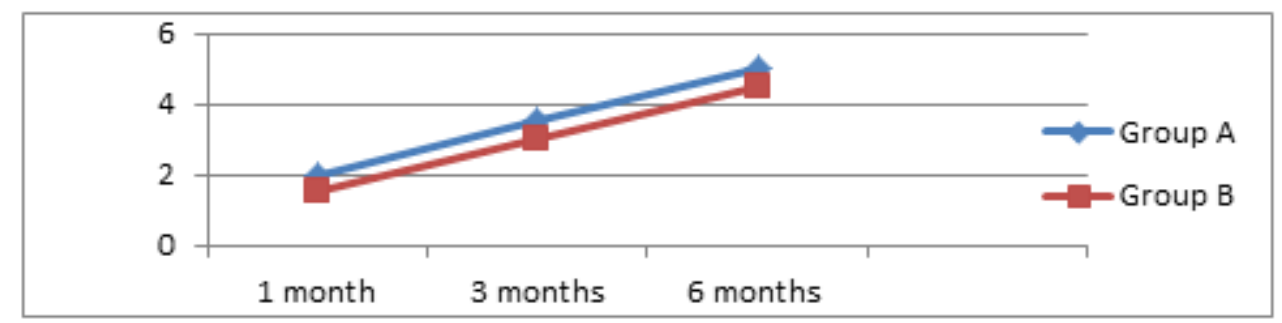

Chart (3):Color fading line graph based on VAS

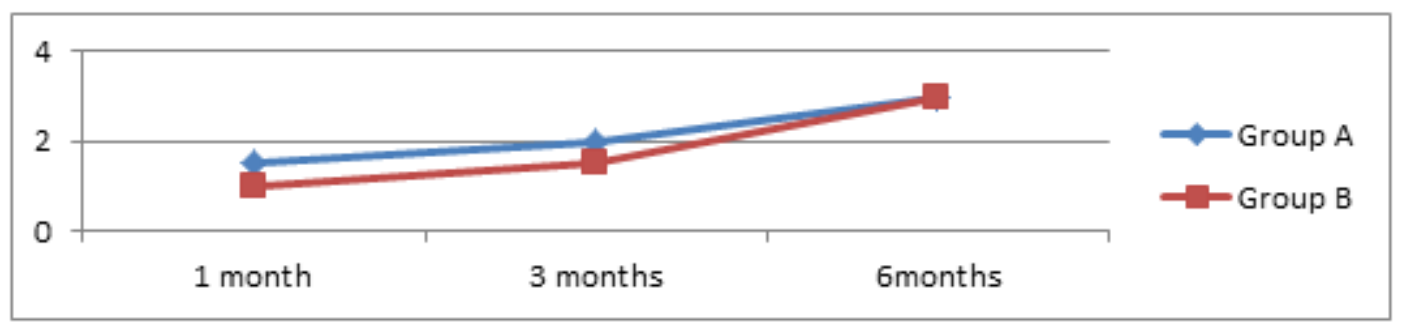

\section{Chart (4): Flattening of the lesions based on VAS}

The auther excluded patients with any contraindication to Beta-blockers like presence of heart disease, cardiac dysrrhythmia, broncho-obstructive disease, history of hypoglycemia, diabetes mellitus, hypertension and hypotension. In Group A, two patients developed hypoglycemia (10\%), two patients developed relapse after stopping the medication(10\%), one patient developed broncho spasm (5\%), while 15 patients without any complications and the drug was well tolerated (75\%) (Chart 5). In Group B, only two patients developed relapse after stopping the treatment (10\%), while 18 patients tolerated the drug adequately $90 \% \quad$ (Chart 6). 


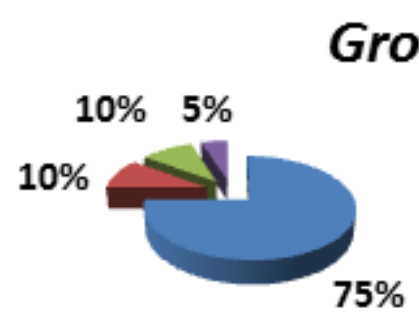

No Complications $(75 \%)$

nypog lyce mia(10\%)

Re lapse(10\%)

Chart (5): Complications in Group A

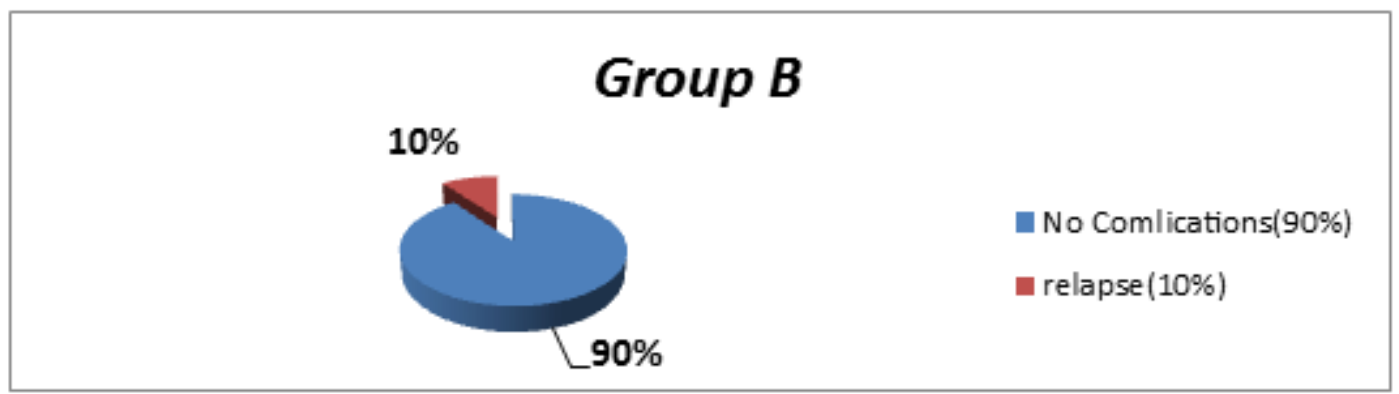

Chart (6): Complications in Group B

\section{DISCUSSION}

In this study, oral and topical propranolol achieved satisfactory results with no significant difference in both groups with the same rate of relapse $(10 \%$ in both groups). The decision to start treating IHs has been controversial over the last decades owing to the unique pattern of growth, yet. Studies showed that most untreated lesions did not improve after 3-5 years of age, and more than $50 \%$ of untreated cases showed significant residum. Therefore, clinicians recommend early active intervention rather than "wait and see" strategy (Baselga et al., 2016). For most clinicians treating complicated IHs, propranolol has become the 1st line medical therapy. However, optimal dosing, treatment duration, timing, and risk of complications have not yet been established in randomized trials, and recommendations for monitoring are still evolving (Drolet et al., 2013).
Many studies showed responses best in patients who had superficial IHs, applying the $0.5 \%$ gel-forming solution, and used it twice daily for more than 3 months (Semkova et al., 2013). Early identification of the lesion is essential in all these patients for prompt management. So, site of IH may dictate the need for further investigations (Zou et al., 2013).

For discontinuation of therapy, gradual tapering of the dose over 1 to 3 weeks basically to avoid rebound sinus tachycardia. Rebound growth of $\mathrm{IH}$ has been reported in $6 \%$ to $25 \%$ of cases often well after their first birthday. Rebound growth may be more likely in patients whose IH exhibited a long proliferative stage and a large subcutaneous component. In such cases, reinitiating of therapy for variable periods of time may be necessary (Giachetti et al., 2014).

In this study, topical propranolol was used for 6 months twice daily as this medication is reasonable for 
uncomplicated superficial IHs for which treatment is desired, but the risk-to-benefit ratio is too great to justify systemic betablocker therapy. However, there are valid concerns regarding the bioavailability of the drug when used topically in neonates and infants, especially in the treatment of larger or ulcerated lesions and those on or near mucous membranes (McMahon et al., 2012).

In this study, topical propranolol could provide with an alternative to oral propranolol which is the 1st line of treatment of IHs, especially in uncomplicated cases. When the treatment was desired by the parents, the site and the size of the lesion did not justify the risk of exposure to the potential side effects of systemic propranolol. Gray scale and color Doppler ultrasonography have demonstrated utility in monitoring the response of $\mathrm{IH}$ to medical therapy (Bingham et al., 2012).

In this study, ultra sonography showed no significant difference between the two groups. As the main goal of treatment is to reduce the cosmetic impairment of the lesions, hence, response to treatment was mainly assessed in terms of cosmetic improvement by using Visual Analogue Scale (VAS). In this study, the degree of color fading by the end of the treatment course was higher in group A compared to group B with no significant statistical difference. Measurement of the degree of flattening of the lesions by using VAS also in the same time intervals showed: in Group A, an improvement especially in the first 3 months of therapy, and at 6 months. The two groups achieved nearly the same results. Within the first 3 to 4 months of using systemic propranolol, the major response on IH occurred. However, some prefer to continue therapy until the age of 8 to 12 months when IH enters the regression phase. Thus, in most studies, propranolol is often continued for 3 to 12 months (Léauté-Labrèze et al., 2015).

In this study, the major response was between the $3^{\text {rd }}$ and $5^{\text {th }}$ month from starting the treatment. At the end of 6 months from starting treatment, patients of this study achieved good response to treatment and it was enough duration. A complete history and physical examination, with attention to the cardiac and pulmonary systems, aid in assessing a child's candidacy for propranolol initiation. ECG is often ordered as well, particularly in younger infants, and those with an examination or family history with congenital heart disease (McMahon et al., 2012).

In this study, patients were excluded with any contraindication to beta-blockers like presence of heart disease, cardiac dysrrhythmia, broncho-obstructive disease, history of hypoglycemia, diabetes mellitus, hypertension and hypotension.

\section{CONCLUSION}

There was no statistical difference between oral and topical propranolol. Choice of one over the other would be a matter of consensus between the managing team and the patient parents. Systemic Propranolol is the 1st line of treatment in IHs, and it is well tolerated with some side effects. Topical Propranolol is good treatment modality.

\section{REFERENCES}

1. Baselga E, Roe E, Coulie J, Munzo FZ, Boon LM, Mccuaig C, Martin AH, Gich I and Puig L (2016): Risk factors for degree and 
type of sequelae after involution of untreated hemangiomas of infancy. JAMA Dermatol., $152: 1239-43$

2. Bingham MM, Saltzman B, Vo NJ and Perkins JA (2012): Propranolol reduces infantile hemangioma volume and vessel density. Otolaryngol Head Neck Surg., 147(2):338-344.

3. Drolet BA, Frommelt PC, Chamlin SL, Haggstrom A, Bauman NM, Chiu YE, Chun RH, Garzon MC, Holland KE, Liberman L, Tobert SM, Mancini AJ, Metry D, Puttgen KB, Seefeldt M, Sidbury R, Ward KM, Blei F, Baselga E, Cassidy L, Darrow DH, Joachim S, Kwon EKM, Martin K, Perkins J, Siegel DH, Boucek RJ and Frieden IJ (2013): Initiation and use of propranolol for infantile hemangioma: report of a consensus conference. Pediatrics, 131(1):128-140.

4. Giachetti A, Garcia-Monaco $R$, Sojo $M$, Scacchi MF, Cernadas C, Lemcke MG and Dovasio F (2014): Long-term treatment with oral propranolol reduces relapses of infantile hemangiomas. Pediatr Dermatol., 31(1):14-20.

5. Léauté-Labrèze $C$, Hoeger $P$, MazereeuwHautier J, Guibaud L, Baselga E, Posiunas G, Phillips RJ, Caceras H, Gutierrez JCL, Ballona R, Friedlander SF, Powell J, Perek D, Metz B, Barbarot S, Maruani A, Szalai
ZZ, Krol A, Boccara O, Holst RF, Bosch MIF, Su J, Buckova H, Torrelo A, Cambazard FGrantzow R, Wargon O, Roessler J, Wittel JB, Valencia AM Pope E, Birchall N and Mancini AJ (2015): A randomized, controlled trial of oral propranolol in infantile hemangioma. N Engl J Med., 372(8):735-746.

6. McMahon P, Oza V and Frieden IJ (2012): Topical timolol for infantile hemangiomas: putting a note of caution in "cautiously optimistic”. Pediatr Dermatol., 29(1):127-130.

7. Semkova K and Kazandjieva J (2013): Topical timolol maleate for treatment of infantile haemangiomas: preliminary results of a prospective study. Clin Exp Dermatol., 38(2):143-146.

8. Zou HX, Jia J, Zhang WF, Sun ZJ and Zhao YF (2013): Propranolol inhibits endothelial progenitor cell homing: a possible treatment mechanism of infantile hemangioma, Cardiovasc Pathol, 22 (3): 203-210. 
إستخدام البروبر انولول عن طريق الفم أو الدهان الموضعي فى الإلى علاج الوحمات الدموية في الأطفال

*أحمد عبدالله خطاب، عبدالوهاب يوسف العقبى، سمير حامد جوده :

$$
\text { قسم الجراحة، كلية الطب، جامعة الأزهر }
$$

E-mail: ahmedabdalla18@yahoo.com

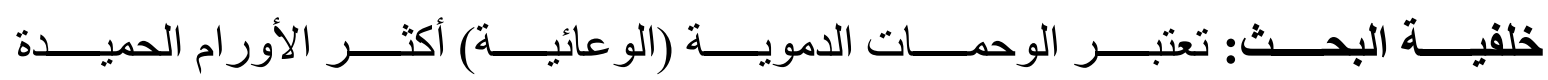

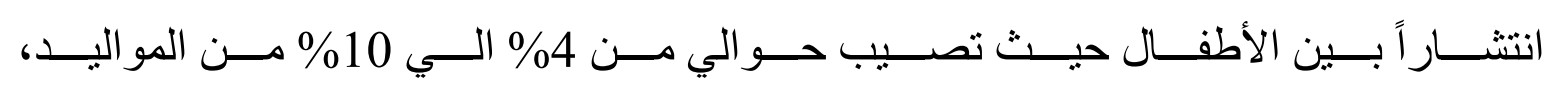

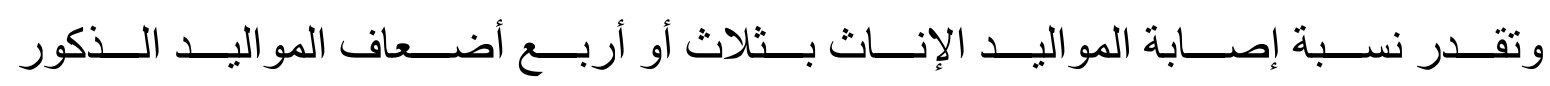
بحسب بعض الأدبيات المنشورة .

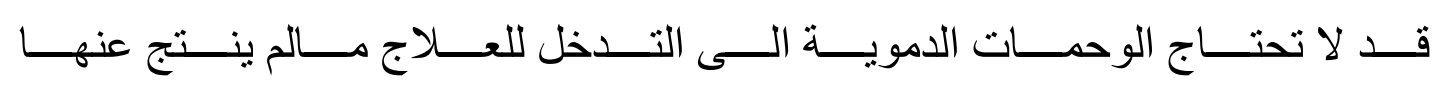
مضاعفات.

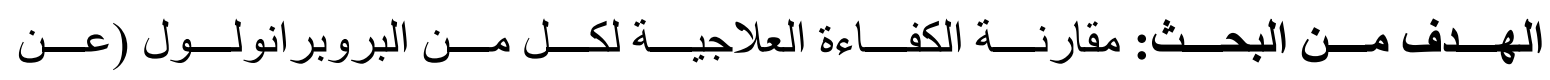
طريق الفم) و الموضعى و ذللك في علاج الوحمات الدموية في الأطفال.

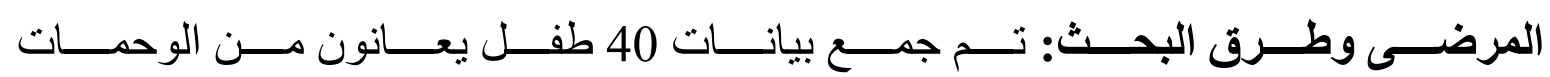

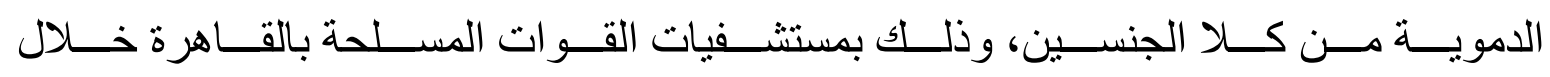
الفترة من فبر اير 2019 الى أكتوبر 2019.

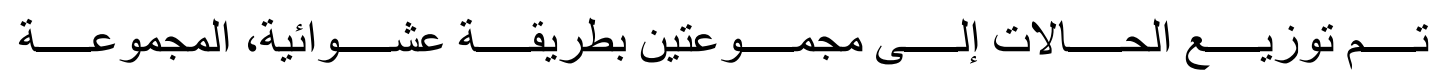

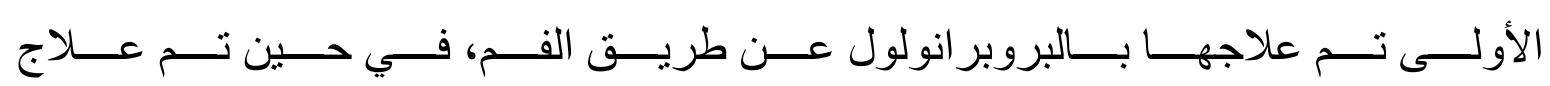
المجمو عة الثانية بالبروبر انولول الموضئ

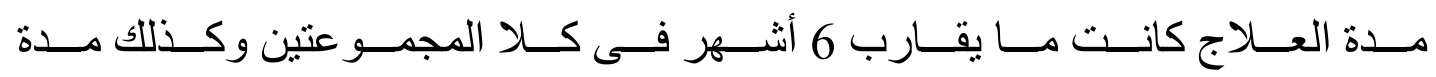
المتابعة بعد إيقاف العلاج فى حدود 3 أثنهر.

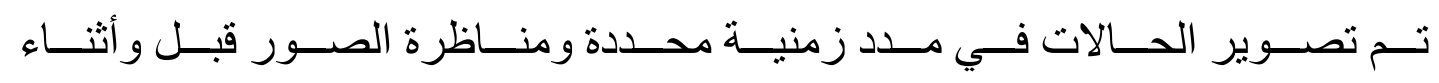
وبعد إنتهاءالعلاج. 
تتــائج البحـــث: اشـــملت عينــة البحـــث علـى 40 طفــلا، 27 مــن الإنــاثـ و 13 مــن

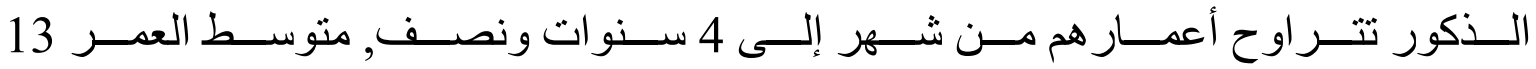

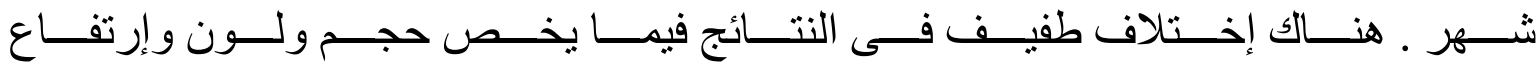

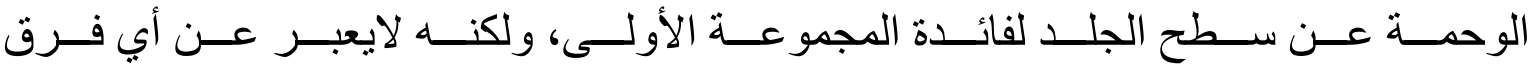

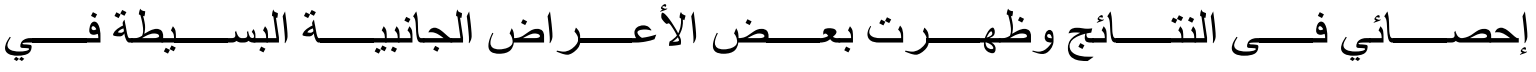
المجموعة الأولى وتم التعامل مع كل حالة بحسب مقتضيات العلاج.

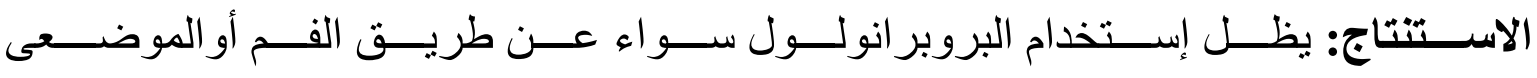

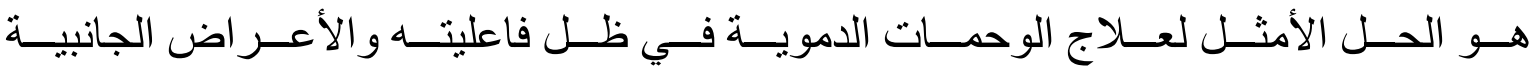

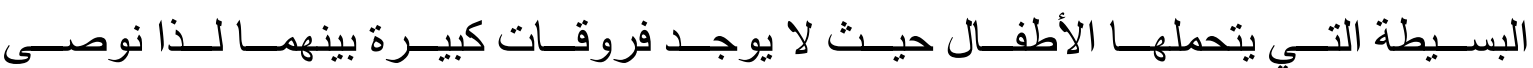
بالتوســع فــى اســـتخدام البروبر انولـــول الموضــــى فــى عـــلاج الوحمــــات الدمويـــة عند الأطفال. 